\title{
SPECIES COMPOSITION, RELATIVE ABUNDANCE AND HABITAT ASSOCIATION OF THE BIRD FAUNA OF THE MONTANE FOREST OF ZEGIE PENINSULA AND NEARBY ISLANDS, LAKE TANA, ETHIOPIA
}

\author{
Shimelis Aynalem and Afework Bekele * \\ Department of Biology, Faculty of Science, Addis Ababa University, PO Box 1176 \\ Addis Ababa, Ethiopia. E-mail: afeworkbekele@hotmail.com
}

\begin{abstract}
The present study was carried out in Zegie Peninsula and Kibran Gebriel and Entos Iyesus Islands of Lake Tana from August 2006 to March 2007. Sampling sites were stratified based on the vegetation type and area cover. Point count technique and chi-square test were employed to see the association of birds with the different vegetation strata. A total of 101 bird species were recorded, out of which 91 were residents (three endemics) and 10 were Palaearctic migrants. The Zegie Peninsula had high species diversity and evenness (0.96 and 0.86, respectively). The relative abundance of birds during the wet and dry seasons was variable. A total of 54 and 68 species were recorded during the wet and dry seasons in the Zegie Peninsula, respectively. The islands possessed 24 species each season. Habitat association of birds within the vegetation strata of Zegie Peninsula during the wet season was: highest at the shore (4.50), followed by gardens (4.00), bushes and shrubs (3.33) and trees (2.17). During the dry season, the highest mean number of birds occurred in the garden vegetation (4.86), followed by trees (3.23), fringe type of vegetation (3.22), and bush and shrub vegetation (2.60). During the wet season, the association of birds with the vegetation stratum was not statistically significant $(p>0.05$, chi-square $=13, \mathrm{df}=7, \mathrm{n}=32)$. However, this was significant during the dry season $(\mathrm{p}<0.05$, chi-square $=66.238, \mathrm{df}=9, \mathrm{n}=84$ ). Conservation action to minimize the anthropogenic effect at Zegie should be the order of the day.
\end{abstract}

Key words/phrases: Avifauna, distribution, habitat association, Zegie Peninsula

\section{INTRODUCTION}

Birds have proved to be excellent indicators of biodiversity or productivity as they are easily observed and are relatively well known compared to other animals. Their dispersal in almost every corner of the globe also makes comparative studies simpler (Dash, 1993; WNHS, 1996; Pomeroy and Dranzoa, 1997). Birds are vital for ecological functioning of our environment such as indicators of pollution, seed dispersal, scavenging offal and as predators of insect pests. The distribution and abundance of many bird species are determined by the composition of the vegetation (habitat) (Lee and Rotenberry, 2005). Climate influences habitats and movements of resident and migratory birds. Many species are characteristic of particular habitats or biomes (Stevenson and Fanshawe, 2002). Dry and wet season movement patterns vary a great deal across the region and between years. The activity of birds, especially in more arid areas, is strongly influenced by the presence or

\footnotetext{
* Author to whom all correspondence should be addressed.

absence of rain (Alertstam, 1982; Stevenson and Fanshawe, 2002).

In Ethiopia, different ecosystems of high biological importance are threatened. Habitat destruction and encroachment of undesirable plant species following flooding and shrinkage of lakes and wetlands are some of the threats to the Ethiopian avifauna (Pol, 2006). Though the country is known for its high biological diversity, studies on the diversity, relative abundance and other ecological aspects of the avian taxa have been little addressed (Urban and Brown, 1971; Ash, 1979; Ash and Gullic, 1989; EWNHS, 1996; Pol, 2006). The Amhara Region of Ethiopia consists of over $75 \%$ of the central Ethiopian Highland IBAs (Important Bird Areas). Nineteen highland biome species have so far been recorded from Lake Tana (EWNHS, 1996). The southern tip of Lake Tana is one of the Important Bird Areas of the country. Zegie Peninsula and the nearby islands are areas where remnant indigenous vegetation still occurs. In addition, the area harbours different species of birds some of which are not yet recorded. The 
species composition, distribution, relative abundance and habitat association of the bird fauna of Zegie Peninsula and nearby islands are hardly addressed. Therefore, the present study attempts to fill this gap.

\section{THE STUDY AREA AND METHODS}

Forest habitat of the Zegie Peninsula and the two islands of Lake Tana (Kibran Gebriel and Entos Iyesus Monastery) were together considered as Entos-Kibran where the present study was conducted (Fig. 1). This area is located in the Amhara National Regional State of Bahir Dar Zone, southern most tip of Lake Tana (110 37' N latitude and $37^{\circ} 25^{\prime} \mathrm{E}$ longitude).

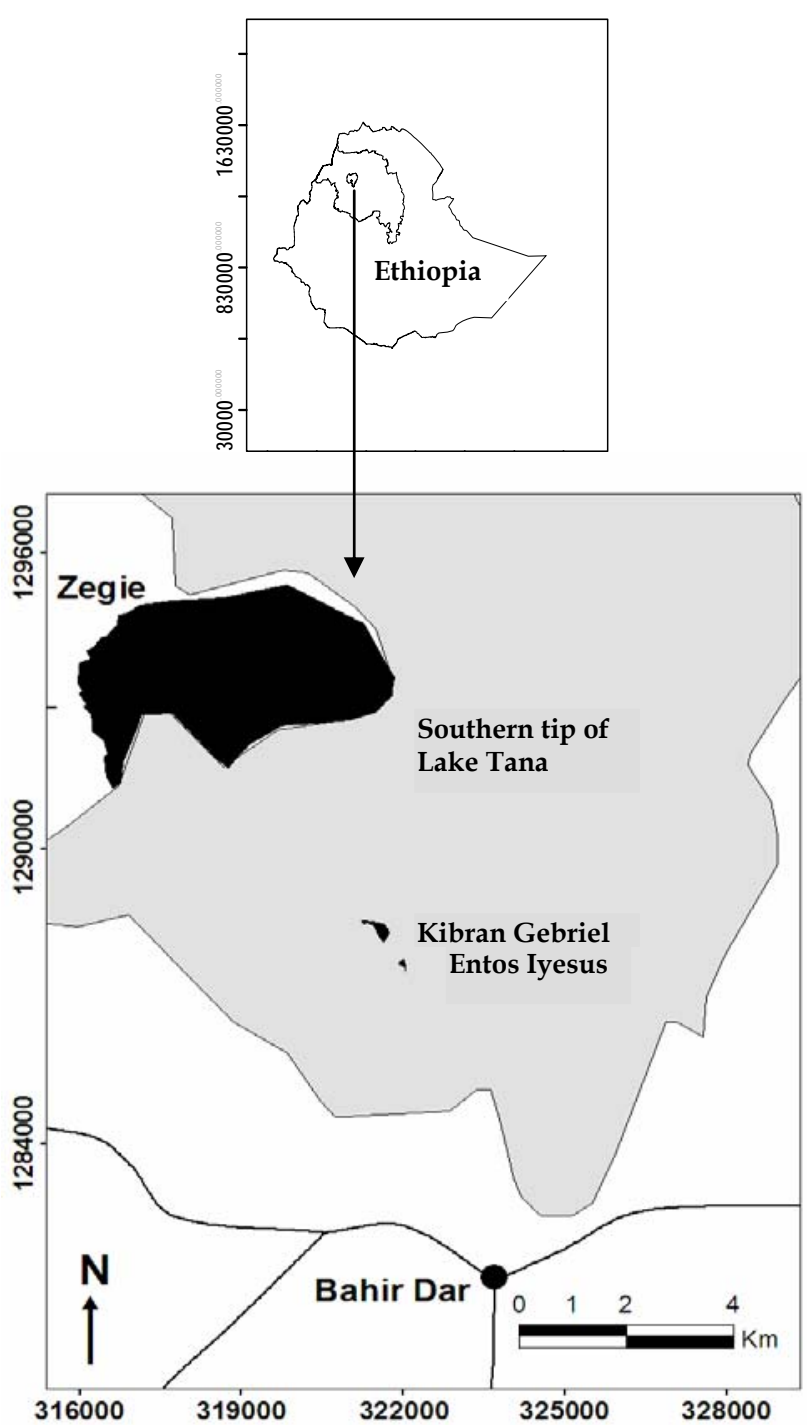

Fig. 1. Location map of the study area.
The Zegie Peninsula has a total area of 1230 ha. The elevation of the area ranges from 1775 to 1985 $\mathrm{m}$ asl. The area is covered with patches of indigenous trees. Kibran Gebriel and Entos Iyesus islands are monasteries that possess montane forest types having a total area of 10 ha (Shimelis Aynalem, 2007).

A preliminary survey was conducted during August 2006. The study was conducted from August 2006 to March 2007, covering both wet and dry seasons. The study area was stratified based on the vegetation type. Though the Zegie Peninsula was considered as a montane forest, within the boundary of the Peninsula, different vegetation structures were clearly observed. Three fourth of the total are is surrounded by Lake Tana. As we move away from the lake shore to the centre, the vegetation structure clearly differs. Habitats around the shore of the Lake adjacent to the Peninsula have an elevation of $1775 \mathrm{~m}$. asl. This area is dominated by different vegetation such as Sizygium guineense and Mimusops kummel. Whereas in the middle of the Peninsula, where the maximum elevation is $1885 \mathrm{~m}$ asl at Yiganda Tekle Haymanot Monastry near Ararat Mountain, the density as well as the distribution and type of vegetation varied, dominated by bush and woodland vegetation. In most places inside the Peninsula where more than 8, 000 inhabitants reside, indigenous trees such as Millettia ferruginea, Cordia africana, Apodytus dimidiate, Rothmannia urcelliformis, Celtis africana and Ficus vasta are the dominant ones. Most coffee plantations are grown in the shade of these trees. The open spaces are covered with vegetable, fruit and home gardens. Hence, the sampling unit within the habitat was determined and assigned on the basis of area coverage and vegetation type: bush and shrubs, fringe vegetation, dominant trees, managed or garden areas. Their proportion to the total study area was approximately $20 \%, 50 \%, 20 \%$ and $10 \%$, respectively. A total of 77 and 102 samples in the Zegie Peninsula, and 17 and 20 in the islands were surveyed during the wet and dry seasons, respectively. The islands are solely devoted for religious purposes with limited inhabitants. The islands are small and are fully covered with indigenous trees including Podocarpus falcatus, Sizygium guineense and Mimusops kummel. The vegetation descriptions of the study area have been carried out by Alemnew Alelign (2001) for the 
Zegie Peninsula and Taye Bekele et al. (2001) for the Islands.

Stratified sampling technique was made based on the methods of Jones (1998) and Krebs (1999). The sampling blocks were randomly selected and assigned based on the stratification of the study area. Sample areas covered 500 ha and 8 ha in Zegie and Entos-Kibran island, respectively. Based on the habitat type, point count method was employed (Sutherland, 1996; Lloyd et al., 1998). To minimize disturbance during the count, a waiting period of 3 to 5 minutes prior to counting was applied (Sutherland, 2000; Hosteler and Main, 2001). The counting at a specific point was accomplished for a fixed period of stay of 3 to 10 minutes interval depending upon the difficulties of the area and the type of bird species to be identified, not to underestimate or overestimate the population of birds, if the counting time is below three minutes and above 10 minutes, respectively. Personal experience, plumage pattern, size and shapes, colour, songs and calls are important parameters used in the identification of birds.

Following Jones (1998), data collection began about 30 minutes after dawn and continued to mid-morning, when bird activity declined. Late afternoon count was also carried out. Where point count technique is employed, the radial distance from which the bird occurred was estimated and then the type and the group number of species were recorded using binoculars. The vegetation type/coverage within $100 \mathrm{~m}$ radial distance from where the count was carried out was also estimated to see the dominant vegetation types, and to study the association of birds in the type of vegetation they were recorded (feeding, resting or/and breeding). Photographs and videos were taken to justify the species type for those species difficult to identify. The songs and calls record of Chappuis (2000), Rochè (1996), and Hammick (2002) were used to relate with the songs and calls of birds heard during the survey period. Species of birds were identified and their taxonomic groups were properly categorized based on field guides (Urban and Brown, 1971; Alden et al., 1995; Alan and Kemp, 2001; van Perlo, 1995; Stevenson and Fanshawe, 2002).

\section{Data analysis}

The data collected were organized in the excel spread sheet for statistical analysis. SPSS (2003) statistical package was used to employ a chisquare test to see the habitat association of birds in each vegetation stratum of the study areas. Simpson's Index (Simpson, 1949) and ShannonWeiner Index (Shannon and Weiner, 1949) were used to evaluate the bird species diversity at different habitats for both seasons.

$$
\begin{aligned}
H^{\prime}=-\sum_{i=1}^{S} P_{i} & \ln P_{i} \quad D=1-\sum_{i=1}^{S} P_{i}^{2} \\
\text { Where } & \\
H^{\prime} & =\text { Shanon-Weiner index } \\
S & =\text { the number of species observed } \\
P_{i} & =\text { the proportion of the total sample } \\
\ln & =\text { natural logarithm } \\
D & =\text { Simpson's Index }
\end{aligned}
$$

Relative abundance of avian species was determined using encounter rates that give crude ordinal scales of abundance (abundant, common, frequent, uncommon and rare) (Bibby et al. 1992, 1998).

$$
\text { Encounter rate }=\frac{\text { Total number of individual birds observed }}{\text { Period of observation in hour }} \times 100
$$

Encounter rate was calculated for each species by dividing the number of birds recorded by the number of hours spent searching, in order to get a figure of birds per hour for each species. The abundance category (the number of individuals per 100 field hr) was: <0.1, 0.1-2.0, 2.1-10.0, 10.140.0 and $40+$. For each category, the following abundance score is given 1 (Rare), 2 (Uncommon), 3 (Frequent), 4 (Common), and 5 (Abundant).

\section{RESULTS}

A total of 101 species of birds belonging to 44 families was observed during the wet and dry seasons (Appendix 1). The Yellow-fronted Parrot (Poicephalus flavifrons) is endemic to Ethiopia; whereas, White-cheeked Turaco (Tauraco leucotis) and Banded Barbet (Lybius undatus) are endemic to Ethiopia and Eritrea. Ninety one resident and 10 Palaearctic migrants were recorded during the study period. During the wet and dry seasons, 78 and 92 bird species were recorded, respectively. Sixty bird species were common for both seasons, but 15 and 26 species were exclusively recorded only during the wet and dry seasons, respectively. 
Wet season species diversity index was high in Entos-Kibran island (0.87). But, evenness of species was high in the Zegie Peninsula (0.9). During the dry season, the species diversity and evenness at the Zegie Peninsula and Entos-Kibran island were 0.94 and 0.61 ; and 0.84 and 0.55 , respectively. Zegie Peninsula had the highest species diversity and evenness (0.96 and 0.86 , respectively) (Table 1 ). The relative abundance score of each species during the wet and dry seasons are shown in Table 2 (see appendices 2, 3, 4 and 5 for more detail). During the dry season, the African Finfoot (Podica senegalensis) in Entos-Kibran island was categorized as a rare species at local level.

The highest number of species was recorded in the Zegie Peninsula during both seasons. A total of 54 and 68 species were recorded during the wet and dry seasons, respectively. The Entos-Kibran island areas had the least number of species (24 species each) during wet and dry seasons. The highest mean number of birds was recorded at the shore of the Zegie Peninsula vegetation stratum: fringe vegetation (4.50), followed by gardens (4.00), bushes and shrubs (3.33) and the least mean number of birds was recorded in the dominant tree stratum (2.17) during the wet season. During the dry season, the highest mean number of birds was recorded in the garden vegetation (4.86), followed by dominant trees (3.23), fringe vegetation (3.22) and the least was in the bush and shrub vegetation (2.60) (Table 3). During the wet season, the association of birds with the vegetation strata (bushes and shrubs, dominant trees including fruit trees, fringes and home gardens including horticultural sites) was not statistically significant ( $p>0.05$, chi-square $=13, d f=7, n=32$ ). During the dry season, however, the association of birds with the different vegetation strata was statistically significant $(\mathrm{p}<0.05$, chi-square $=66.238, \mathrm{df}=9$, $\mathrm{n}=84$ ).

Table 1. Avian species diversity during the wet and dry seasons.

\begin{tabular}{lllllll}
\hline \multirow{2}{*}{ Study area } & Season & $\begin{array}{l}\text { No. of } \\
\text { species }\end{array}$ & $\begin{array}{l}\text { Individual } \\
\text { Abundance }\end{array}$ & D & $\mathrm{H}^{\prime}$ & $\mathrm{H}^{\prime} / \mathrm{H}^{\prime} \mathrm{max}$ \\
\hline \multirow{3}{*}{ Zegie Peninsula } & Wet & 52 & 222 & 0.59 & 3.86 & 0.90 \\
& Dry & 68 & 535 & 0.94 & 3.56 & 0.84 \\
& Both seasons & 92 & 757 & 0.96 & 3.87 & 0.86 \\
& & & & & \\
\multirow{2}{*}{ Entos-Kibran island } & Wet & 24 & 159 & 0.87 & 2.49 & 0.63 \\
& Dry & 24 & 250 & 0.61 & 1.69 & 0.55 \\
\hline
\end{tabular}

Note: $\mathrm{H}^{\prime}=$ Shannon-Weiner Index; $\mathrm{H}^{\prime} / \mathrm{H}^{\prime} \max =$ Evenness; $\mathrm{D}=$ Diversity Index; $\mathrm{H}^{\prime} \max =\ln (\mathrm{S})$; $\mathrm{S}=$ The total number of species.

Table 2. Relative abundance of birds during the wet and dry seasons.

\begin{tabular}{lllllll}
\hline \multirow{2}{*}{ Study area } & Season & \multicolumn{5}{c}{ Number of } \\
\cline { 3 - 6 } & & $\begin{array}{l}\text { rare } \\
\text { species }\end{array}$ & $\begin{array}{l}\text { uncommon } \\
\text { species }\end{array}$ & $\begin{array}{l}\text { frequent } \\
\text { species }\end{array}$ & $\begin{array}{l}\text { common } \\
\text { species }\end{array}$ & $\begin{array}{l}\text { abundant } \\
\text { species }\end{array}$ \\
\hline \multirow{2}{*}{ Zegie Peninsula } & Wet & & 25 & 22 & 4 & - \\
& Dry & & 28 & 24 & 15 & 1 \\
\multirow{2}{*}{$\begin{array}{l}\text { Entos-Kibran } \\
\text { island }\end{array}$} & Wet & & - & 7 & 11 & 7 \\
\hline
\end{tabular}

Table 3. Number of species in the different vegetation strata of Zegie Peninsula (mean \pm SE).

\begin{tabular}{lllll}
\hline \multirow{2}{*}{ Season } & \multicolumn{4}{c}{ Vegetation strata } \\
\cline { 2 - 5 } Wet & Bush & Trees & Fringes & Gardens \\
\hline \multirow{2}{*}{ Dry } & $3.33 \pm .67$ & $2.17 \pm .60$ & $4.50 \pm .50$ & $4.00 \pm 1.78$ \\
& $2.60 \pm .34$ & $3.23 \pm .36$ & $3.22 \pm .46$ & $4.86 \pm 1.21$ \\
\hline
\end{tabular}


An association of birds to a certain type of plant species was observed during the study period. Fruit trees, mainly C. africana, F. vasta and $F$. sycamorus were observed to support a large number of species such as: greater blue-eared glossy starling, red-winged starling, violet-backed starling, eastern-grey plantain-eater, bare-faced and white-bellied go-away-bird, speckled mousebird, yellow-mantled widowbird, and yellowfronted thinkerbird; whereas, bronze sunbird, collared sunbird, scarlet-chested sunbird, and variable sunbird were associated with flower bearing trees, shrubs and vegetable gardens. On the fringes or mangrove of Zegie Peninsula, along the shore of the lake, where S. guineense and $M$. kummel trees were dominant, the African fish eagle and Kingfishers were associated as a resting site. As these species depended on fish, they require such trees for resting and watching to dive in the water and capture the prey.

\section{DISCUSSION}

The highland biome species such as the Yellowfronted Parrot (P. flavifrons), White-cheeked Turaco (T. leucotis) and Banded Barbet (L. undatus), occurred in substantial numbers. It was based on the abundance score calculated for Zegie peninsula. This was due to the favourable environment of the habitat that supported the species in different ways. Trees particularly, C. africana and F. vasta are used for nesting, breeding, feeding and sheltering sites for these species. These trees are far from being approached by predators, and human interference; and are also known to produce edible fruits. In addition, the large size of the Peninsula with good vegetation and canopy cover helped to have an ideal habitat for the species. The species diversity index and evenness of the areas during the wet and dry seasons revealed that Zegie Peninsula had more species diversity and evenness than the islands. The outcome of this result coincides with the report of Karr (1976); Janzen (1967) and Smythe (1970) where structurally complex vegetation buffers the influence of seasonality and there is a great stability in resource availability, which allows species to occur as residents throughout the year. The stability of the micro-climate of the Zegie Peninsula compared to the small patch areas of the Islands has contributed to the high species evenness of the area. The small scrap of the islands was difficult to support a large number of birds and the close location of islands to the Peninsula resulted in the low evenness of the species.

The relative abundance of birds in the study area is related to the availability of food, habitat condition and breeding season of the species. According to Karr and Roth (1971), the distinct seasonality of rainfall and seasonal variation in the abundance of food resources result in seasonal changes in the abundance of birds. The number of uncommon species registered at Zegie Peninsula was high. Those species which have low number of individuals relative to the effort made during the survey compared to others were grouped in the uncommon category. This result can be related to the degradation of habitats that are important for feeding, resting, roosting and breeding. The degradation could be due to vegetation clearing, burning, and habitat modification. Such type of disturbance and degradation of the habitat would reduce the individual population of the species in many ways. Cutting trees and clearing vegetation for coffee plantation and fire wood production to sell to the nearest town were common in the area. Ryan and Owino (2006) suggested that the presence of large number of uncommon species in a certain area could be related to the breeding nature, large home range and niche of the species; besides the degradation of the habitat. In addition, Karr (1976) suggested that the number of individual birds varied independently within the study area. Some species abandon the specified area, decreasing both in the number of species and individuals, while others may have a reduced number but may be present as a few scattered individuals throughout the year. Even species with a relatively stable population will tend to show variation in abundance and occupancy over time (Gaston et al, 2000). For example, the African Finfoot (P. senegalensis) at Entos-Kibran island was rare. The rarity of the African Finfoot is related to the degradation or patchiness of the habitat. According to Wilson and Comet (1996), the absence or rarity of several species appeared to be related to habitat condition. Thiollay (1994) suggested that species that are consistently rare have either large home range or patchily distributed.

The distribution and abundance of many bird species are determined by the composition of the vegetation that comprises a major element of their habitats (Lee and Rotenberry, 2005). In the vegetation strata of Zegie Peninsula, species have shown different associations with the type of vegetation. Along the whole vegetation gradient (slope), most bird species tended to be related with structural variables. Within smaller sub-groups of 
sites, some bird species were more associated with a particular plant species: fruit trees, flowering trees, bushes or shrubs (Estades, 1997). The highland biome species, particularly, the yellow fronted parrot, banded barbet, white-cheeked turaco, black-billed and double-toothed barbets and Narina's trogon were highly associated with fruit trees in the Zegie Peninsula, as distinctive plant communities often support quite different bird species (Wilson and Comet, 1996).

It is impossible to apply absolute density to estimate the relative abundance of each species of birds in a multi-species study and a dense vegetation, rather encounter rate is more appropriate. The data provided by the encounter rates do not provide an accurate indication of abundance and are not a substitute for density estimate. In addition, the relative abundance of species has no relation with IUCN species category criteria rather it is useful to know the abundance of the species in a particular area.

\section{ACKNOWLEDGEMENTS}

This study was sponsored by The Zoological Natural History Museum, Development Innovative Fund (DIF) and Addis Ababa University. Additional financial assistance from the Frankfurt Zoological Society is also acknowledged.

\section{REFERENCES}

1. Alan, D. and Kemp, M. (2001). Sasol: Birds of Prey of Africa and its Islands. Struik Publishers, Cape Town, 347 pp.

2. Alden, P. C., Estes, R. D., Schlitter, D. and McBride, B. (1995). National Audubon Society Field guide to African Wildlife. Chanticleer Press, New York, 988 pp.

3. Alemnew Alelign (2001). Diversity and socio-economic importance of woody plants on the peninsula of Zegie, Northwestern Ethiopia: implications for their sustainable utilization. MSc. Thesis, Wondo Genet Forestry College, Wondo Genet. 83 pp

4. Alertstam, T. (1982). Bird Migration. Cambridge University Press, Cambridge, 409 pp.

5. Ash, J. C. (1979). A new species of Serin from Ethiopia. Ibis 121:1-7.

6. Ash, J.S. and Gullic, T.M. (1989). The present situation regarding endemic breeding birds of Ethiopia. Scopus 13:90-96.

7. Bibby, C.J., Collar, N.B., Crosby, M.J., Heath, M.F., Imboden, C., Jonston, T.H. Long, A.J., Satterfield, A.J. and Thirgood, S.J. (1992).
Putting Biodiversity on the Map: Priority Areas for Global Conservation. Barrington Press, Cambridge, 239 pp.

8. Bibby, C., Jones, M. and Marsden, S. (1998). Expedition Field Techniques: Bird Surveys. Royal Geographical Society, London, 134 pp.

9. Chappuis, C. (2000). African Bird Sounds: Birds of North, West and Central Africa. Sociètè d'Etudes Ornithologiques de France, Paris.

10. Dash, M. C. (1993). Fundamentals of Ecology, $2^{\text {nd }}$ ed.. Tata McGraw-Hill Publishing Company Ltd., New Delhi, 519 pp.

11. Estades, F. C. (1997). Bird-habitat relationships in vegetation gradient in the Andes of Central Chile. Condor 99:719-727.

12. EWNHS (1996). Important Bird Areas of Ethiopia. Ethiopian Wildlife and Natural History Society, Addis Ababa, 300 pp.

13. Gaston, K.J., Blackburn, T.M., Greenwoodx, J.D., Greroryx, R.D., Rachel, M.Q. and Lawton, J.H. (2000). Abundance-occupancy relationships. J. App. Ecol. 37:39-59.

14. Hammick, J. (2002). The bird songs of Kenya and Tanzania (CD): an introductory aid to identification. Mandarin Productions, Arusha.

15. Hostetler, M.E. and Main, M.B. (2001). Florida Monitoring Program: Transect and Point Count Method for Surveying Birds. University of Florida, Florida, $28 \mathrm{pp}$.

16. Janzen, D.H. (1967). Synchronization of sexual reproduction of trees within the dry season in Central America. Evol. 21:620-637.

17. Jones, M. (1998). Study design. In: Expedition Field Techniques: Bird Surveys, pp. 15-34, (Bibby, C., Jones, M. and Marseden, S. eds). Royal Geographical Society, London.

18. Karr, J.R. (1976). Seasonality, resource availability, and community diversity in tropical bird communities. Am. Natur. 110:973-994.

19. Karr, J.R. and Roth, R.R. (1971). Vegetation structure and avian diversity in several New World areas. Am. Natur. 105:423-435.

20. Krebs, C. J. (1999). Ecological Methodology, 2nd ed. Addison-Welsey Educational Publishers, Inc., California, 620 pp.

21. Lee, P. and Rotenberry, J.T. (2005). Relationships between bird species and tree species assemblages in forested habitats of eastern North America. J. Biogeogr. 32:1139-1150.

22. Lloyd, H., Cahill, A., Jones, M. and Marsden, S. (1998). Estimating bird densities using distance sampling. In: Expedition Field Techniques: Bird Surveys, pp. 35-52, (Bibby, C. Jones, M. and Marseden, S. eds). Royal Geographical Society, London.

23. Ryan, P.G. and Owino, A.O. (2006). Habitat Association of Papyrus Specialist Birds at Three Papyrus 
Swamps in Western Kenya. Blackwell Publishing Ltd., Nairobi, pp. 1-6.

24. Rochè, J.C. (1996). Bird Songs and Calls of Britain and Europe (CDs). UK Wild Sounds Publisher, Salthouse, Norfolk.

25. Pol, J.L.V. (2006). A Guide to Endemic Birds of Ethiopia and Eritrea, 2nd ed. Shama Books, Addis Ababa, $80 \mathrm{pp}$.

26. Pomeroy, D. and Dranzoa, C. (1997). Methods of studying the distribution, diversity and abundance of birds in East Africa some quantitative approaches. Afr. J. Ecol. 35:110-123.

27. Shannon, C.E. and Weiner, P. (1949). The Mathematical Theory of Communication. University of Illinois Press, Urbana, 117 pp.

28. Shimelis Aynalem (2007). Species Composition, Distribution, Relative Abundance and Habitat Association of the Bird Fauna of Bahir Dar, Zegie Peninsula and the Nearby Islands of Lake Tana, Bahir Dar. MSc. Thesis, Addis Ababa University, Addis Ababa, 107 pp.

29. Simpson, E.H. (1949). Measurement of diversity. Nature 163:688.

30. Smythe, N. (1970). Relationships between fruiting seasons and seed dispersal methods in a Neotripical Forest. Am. Natur. 104:25-35.

31. SPSS (2003). Statistical Package for Social Sciences version 12 application guide. SPSS Inc. Chicago.

32. Stevenson, T. and Fanshawe, J. (2002). Field Guide to the Birds of East Africa: Kenya, Tanzania,
Uganda, Rwanda and Burundi. T and A D Poyser Ltd. London, 602 pp.

33. Sutherland, W.J. (1996). Ecological Census Techniques: A Handbook. Cambridge University Press, London, $336 \mathrm{pp}$.

34. Sutherland, W.J. (2000). The Conservation Hand Book Research, Management and Policy. Blackwell Science Ltd., London, 278 pp.

35. Taye Bekele, Getachew Berhan, Sisay Zerfu and Kumlachew Yeshitela (2001). Perspective of the Ethiopian Orthodox Tewahido Church in Forest Biodiversity Conservation. In: Biodiversity Conservation in Ancient Church and Monastry Yards in Ethiopia, pp. 9-18, (Taye Bekele, Getachew Berhan, Sisay Zerfu and Kumlachew Yeshitela eds). Unpublished. Addis Ababa.

36. Thiollay, J. (1994). Structure, density and rarity in an Amazonian Rainforest bird community. J. Trop. Ecol. 10:449-481.

37. Urban, E.K. and Brown, L.H. (1971). A Checklist of the Birds of Ethiopia. Haile Selassie I University Press, Addis Ababa, 143 pp.

38. van Perlo, B. (1995). Birds of Eastern Africa, Collins Illustrated Checklist. Harper Collins Publishers Ltd., London, 301 pp.

39. Wilson, M.F. and Comet, T.A. (1996). Bird communities of northern forests: patterns of diversity and abundance. Condor 98:337-349.

Appendix 1. Bird species recorded during the wet and dry seasons.

\begin{tabular}{|c|c|c|c|}
\hline Species & $\begin{array}{l}\text { Wet } \\
\text { season }\end{array}$ & $\begin{array}{l}\text { Dry } \\
\text { season }\end{array}$ & All seasons \\
\hline Abyssinian White-eye (Zosterops abyssinicus) & & + & \\
\hline African Citril (Serinus citrinelloides ) & & & + \\
\hline African Collared (Rose-Grey) Dove (Streptopelia roseogrisea) & + & & \\
\hline African Cuckoo (Cuculus gularis) & + & & \\
\hline African Darter (Anhinga rufa) & & + & \\
\hline African Finfoot (Podica senegalensis) & & + & \\
\hline African Fish-Eagle (Haliaeetus vocifer) & & & + \\
\hline African Harrier-Hawk (Polyboroides typus) & & & + \\
\hline African Jacana (Actophilornis africana) & & + & \\
\hline African Little Sparrowhawk (Accipiter minullus) & + & & \\
\hline African Paradise Flycatcher (Terpsiphone viridis) & & & + \\
\hline African Pied Wagtail (Motacilla aguimp) & & & + \\
\hline African pygmy-Kingfisher (Ispidina picta) & & + & \\
\hline Baglafecht Weaver (Ploceus baglafecht) & & & + \\
\hline Banded Barbet (Lybius undatus ) & & & + \\
\hline Bare-faced Go-away-bird (Corythaixoides personatus) & + & & \\
\hline Bearded Woodpecker (Dendropicos namaquus ) & & & + \\
\hline Black Cap (Sylvia atricapilla) & & + & \\
\hline
\end{tabular}




\begin{tabular}{|c|c|c|c|}
\hline Species & $\begin{array}{l}\text { Wet } \\
\text { season }\end{array}$ & $\begin{array}{l}\text { Dry } \\
\text { season }\end{array}$ & All seasons \\
\hline Black Crake (Amaurornis flavirostris) & & & + \\
\hline Black Kite/ Yellow-billed Kite (Milvus migrans /parasiticus) & & & + \\
\hline Black-billed Barbet (Lybius guifsobalito ) & & & + \\
\hline Black-billed Wood-dove (Turtur abyssinicus) & & + & \\
\hline Black-crowned Tchagra (Tchagra senegala) & + & & \\
\hline Black-headed Batis (Batis minor) & & & + \\
\hline Black-headed Oriole (Oriolus larvatus) & & & + \\
\hline Black-headed Weaver (Ploceus melanocephalus) & & & + \\
\hline Blue-breasted Bee-eater (Merops variegates ) & & & + \\
\hline Blue-headed Coucal (Centropus monachus) & & & + \\
\hline Blue-spotted Wood-Dove (Turtur afer) & & + & \\
\hline Brown-throated Wattle-eye (Platysteira cyanea) & & & + \\
\hline Bruce's Green-Pigeon (Treron waalia) & + & & \\
\hline Cattle Egret (Bubulcus ibis ) & & & + \\
\hline Collared Sunbird (Anthreptes collaris) & & & + \\
\hline Common Bulbul (Pycnonotus barbatus) & & & + \\
\hline Common Fiscal (Lanius collaris) & + & & \\
\hline Common Sandpiper (Actitis hypoleucos) & & & + \\
\hline Common Stonechat (Saxicola torquata) & & + & \\
\hline Copper (Coppery) Sunbird (Cinnyris cupreus) & & & + \\
\hline Double-toothed Barbet (Lybius bidentatus) & & & + \\
\hline Eastern Grey Plantian-eater (Crinifer zonurus) & & & + \\
\hline Egyptian goose (Alopochen aegyptiacus) & & & + \\
\hline Eurasian Hoopoe (Upupa epops) & & & + \\
\hline European Turtle-Dove (Streptopelia turtur) & & + & \\
\hline Fan-tailed Widowbird (Euplectes axillaries) & & + & \\
\hline Giant Kingfisher (Megaceryle maximus) & & + & \\
\hline Great Reed-Warbler (Acrocephalus arundinaceus) & & + & \\
\hline Greater Blue-eared glossy-Starling (Lamprotornis chalbeus) & & & + \\
\hline Great-white Egret (Egretta alba) & & + & \\
\hline Grey Woodpecker (Dendropicos goertae ) & & & + \\
\hline Grey-backed Camaroptera (Camaroptera brevicaudata) & & & + \\
\hline Grey-headed Sparrow (Passer griseus) & & & + \\
\hline Hamerkop (Scopus umbretta) & & & + \\
\hline Hemprich's Hornbill (Tockus hemprichii) & & & + \\
\hline Jameson's Firefinch (Lagonosticta rhodopareia) & + & & \\
\hline Laughing (Palm) Dove (Streptopelia senegalensis) & & & + \\
\hline Lemon Dove (Columba larvata) & & & + \\
\hline Little Bee-eater (Merops pusillus) & & & + \\
\hline Little Egret (Egretta garzetta) & & + & \\
\hline Little Weaver (Ploceus luteolus ) & + & & \\
\hline Long-tailed Cormorant (Phalacrocorax africanus) & & & + \\
\hline Malachite Kingfisher (Alcedo cristata) & & & + \\
\hline Marsh Warbler(Acrocephaalus palustris) & & + & \\
\hline Narina's Trogon (Apaloderma narina) & & + & \\
\hline Northern Black Flycatcher (Melaenornis edolioides) & & & + \\
\hline Northern Puffback (Dryoscopus gambensis) & & & + \\
\hline Nubian Woodpecker (Campethera nubica) & + & & \\
\hline Olivaceous Warbler (Hippolais pallida) & & + & \\
\hline Olive Thrush (Turdus olivaceus ) & + & & \\
\hline Open-billed Stork (Anastomus lamelligerus ) & & + & \\
\hline Osprey (Pandion haliaetus) & & + & \\
\hline
\end{tabular}




\begin{tabular}{|c|c|c|c|}
\hline Species & $\begin{array}{l}\text { Wet } \\
\text { season }\end{array}$ & $\begin{array}{l}\text { Dry } \\
\text { season }\end{array}$ & All seasons \\
\hline Pied Kingfisher (Ceryle rudis ) & & & + \\
\hline Pied Wagtail (Motacilla alba) & & & + \\
\hline Red-billed Firefinch (Lagonosticta senegala) & & & + \\
\hline Red-cheeked Cordonbleu (Uraeginthus bengalus) & & & + \\
\hline Red-chested Cuckoo (Cuculus solitarius) & + & & \\
\hline Red-eyed Dove (Streptopelia semitorquata) & & & + \\
\hline Red-winged Starling (Onychognathus morio ) & & & + \\
\hline Rueppell's Robin-Chat (Cossypha semirufa) & & & + \\
\hline Sand Martin (Back Swallow) (Riparia riaipa) & & & + \\
\hline Scarlet-chested Sunbird (Chalcomitra senegalensis) & & & + \\
\hline Sedge Warbler (Acrocephalus schoenobaenus) & & + & \\
\hline Silvery-cheeked Hornbill (Ceratogymna brevis) & & & + \\
\hline Southern Masked Weaver (Ploceus velatus) & + & & \\
\hline Speckled Mousebird (Colius striatus) & & & + \\
\hline Speckled Pigeon (Columba guinea) & & & + \\
\hline Spectacled Weaver (Ploceus ocularis) & & & + \\
\hline Squacco Heron (Ardeola ralloides) & & & + \\
\hline Streaky Seedeater (Serinus striolatus ) & & + & \\
\hline Striped Kingfisher (Halcyon chelicuti) & & & + \\
\hline Tacazze Sunbird (Nectarina tacazze) & & + & \\
\hline Tropical Boubou (Laniarius aethiopicus) & & & + \\
\hline Variable (Yeloow-bellied) Sunbird (Cinnyris venustus) & + & & \\
\hline Village Indigobird (Vidua chalybeate) & & & + \\
\hline Violet-backed Starling (Cinnyricinclus leucogaster) & & + & \\
\hline White-cheeked Turaco (Tauraco leucotis ) & & & + \\
\hline White-Fronted Black Chat (Myrmecocichla albifrons) & + & & \\
\hline White-headed Vulture (Trigonoceps occipitalis) & & + & \\
\hline White-winged Tern (Chliodonias leucopterus) & & & + \\
\hline Yellow-billed Egret (Egretta intermedia) & & & + \\
\hline Yellow-fronted Parrot (Poicephalus flavifrons) & & & + \\
\hline Yellow-fronted Tinkerbird (Pogoniulus chrysoconus) & & + & \\
\hline
\end{tabular}

\section{Appendix 2. Relative abundance of birds from Zegie Peninsula during the wet season.}

\begin{tabular}{llll}
\hline Common name & $\begin{array}{l}\text { Number of } \\
\text { individuals }\end{array}$ & Abundance score & Relative abundance \\
\hline Black- headed Oriole & 1.0 & 2 & Uncommon \\
African Collared-Dove & 8.0 & 3 & Frequent \\
African Cuckoo & 1.0 & 2 & Uncommon \\
African Fish-Eagle & 1.0 & 2 & Uncommon \\
African Little Sparrowhawk & 2.0 & 2 & Uncommon \\
African Paradise Flycatcher & 7.0 & 3 & Frequent \\
Baglafecht Weaver & 7.0 & 3 & Frequent \\
Banded Barbet & 6.0 & 3 & Frequent \\
Brown-throated Wattle-eye & 1.0 & 2 & Uncommon \\
Bearded Woodpecker & 6.0 & 3 & Frequent \\
Black-backed Puffback & 1.0 & 2 & Uncommon \\
Black-crowned Tchagra & 1.0 & 2 & Uncommon \\
Blue-headed Coucal & 3.0 & 3 & Frequent
\end{tabular}




\begin{tabular}{|c|c|c|c|}
\hline Common name & $\begin{array}{l}\text { Number of } \\
\text { individuals }\end{array}$ & Abundance score & Relative abundance \\
\hline Copper Sunbird & 1.0 & 2 & Uncommon \\
\hline Montagu's Harrier & 1.0 & 2 & Uncommon \\
\hline Collared Sunbird & 5.0 & 3 & Frequent \\
\hline Common Bulbul & 15.0 & 4 & Common \\
\hline Common Fiscal & 6.0 & 3 & Frequent \\
\hline Double-toothed Barbet & 2.0 & 2 & Uncommon \\
\hline Eastern Grey Plantain-eater & 2.0 & 2 & Uncommon \\
\hline Giant Kingfisher & 3.0 & 3 & Frequent \\
\hline Grey Woodpecker & 3.0 & 3 & Frequent \\
\hline Grey-headed Sparrow & 8.0 & 3 & Frequent \\
\hline Hamerkop & 4.0 & 3 & Frequent \\
\hline Jameson's Firefinch & 12.0 & 4 & Common \\
\hline Laughing Dove & 2.0 & 2 & Uncommon \\
\hline Lemon Dove & 3.0 & 3 & Frequent \\
\hline Little Bee-eater & 23.0 & 4 & Common \\
\hline Little Weaver & 2.0 & 2 & Uncommon \\
\hline Malachite Kingfisher & 2.0 & 2 & Uncommon \\
\hline Northern Black-Flycatcher & 1.0 & 2 & Uncommon \\
\hline Northern Masked Weaver & 1.0 & 2 & Uncommon \\
\hline Southern Masked Weaver & 5.0 & 3 & Frequent \\
\hline Nubian Woodpecker & 1.0 & 2 & Uncommon \\
\hline Pied Kingfisher & 1.0 & 2 & Uncommon \\
\hline Red-chested Cuckoo & 1.0 & 2 & Uncommon \\
\hline Red-eyed Dove & 7.0 & 3 & Frequent \\
\hline Red-winged Starling & 5.0 & 3 & Frequent \\
\hline Rueppell's Robin-Chat & 4.0 & 3 & Frequent \\
\hline Scarlet-chested Sunbird & 1.0 & 2 & Uncommon \\
\hline Silvery-cheeked Hornbill & 4.0 & 3 & Frequent \\
\hline Speckled Mousebird & 3.0 & 3 & Frequent \\
\hline Speckled Pigeon & 6.0 & 3 & Frequent \\
\hline Spectacled Weaver & 2.0 & 2 & Uncommon \\
\hline Tropical Boubou & 10.0 & 3 & Frequent \\
\hline Village Indigobird & 2.0 & 2 & Uncommon \\
\hline White-cheeked Turaco & 1.0 & 2 & Uncommon \\
\hline White-fronted Black Chat & 1.0 & 2 & Uncommon \\
\hline Yellow-billed Egret & 5.0 & 3 & Frequent \\
\hline Yellow-fronted Parrot & 16.0 & 4 & Common \\
\hline
\end{tabular}


Appendix 3. Relative abundance of birds from Entos-Kibran island during the wet season.

\begin{tabular}{|c|c|c|c|}
\hline Common Name & $\begin{array}{l}\text { Number of } \\
\text { individuals }\end{array}$ & Abundance score & Relative abundance \\
\hline African Darter & 6.7 & 3 & Frequent \\
\hline African Fish-Eagle & 13.3 & 4 & Common \\
\hline Bruce's Green Pigeon & 6.7 & 3 & Frequent \\
\hline African Harrier Hawk & 6.7 & 3 & Frequent \\
\hline African Paradise Flycatcher & 53.3 & 5 & Abundant \\
\hline African Pied Wagtail & 13.3 & 4 & Common \\
\hline Black Crake & 100.0 & 5 & Abundant \\
\hline Black Kite & 153.3 & 5 & Abundant \\
\hline Black-backed Puffback & 6.7 & 3 & Frequent \\
\hline Black-billed Wood-Dove & 13.3 & 4 & Common \\
\hline Common Bulbul & 46.7 & 5 & Abundant \\
\hline Sand-Martin & 13.3 & 4 & Common \\
\hline White-winged Tern & 40.0 & 4 & Common \\
\hline Eastern Grey Plantian-eater & 26.7 & 4 & Common \\
\hline Egyptian Goose & 13.3 & 4 & Common \\
\hline Eurasian Hoopoe & 6.7 & 3 & Frequent \\
\hline Grey-headed Sparrow & 33.3 & 4 & Common \\
\hline Hamerkop & 6.7 & 3 & Frequent \\
\hline Long-tailed Cormorant & 306.7 & 5 & Abundant \\
\hline Malachite Kingfisher & 6.7 & 3 & Frequent \\
\hline Olive Trush & 60.0 & 5 & Abundant \\
\hline Red-eyed Dove & 86.7 & 5 & Abundant \\
\hline Speckled Pigeon & 26.7 & 4 & Common \\
\hline
\end{tabular}

Appendix 4. Relative abundance of birds from Zegie Peninsula during the dry season.

\begin{tabular}{llll}
\hline Common Name & $\begin{array}{l}\text { Number of } \\
\text { individuals }\end{array}$ & Abundance score & Relative abundance \\
\hline Abyssinian White-eye & 10 & 3 & Frequent \\
Black-headed Oriole & 2 & 2 & Uncommon \\
African Citril & 12 & 4 & Common \\
African Darter & 2 & 2 & Uncommon \\
African Fish-Eagle & 1 & 2 & Uncommon \\
African Jacana & 2 & 2 & Uncommon \\
African Paradise Flycatcher & 21 & 4 & Common \\
African Pygmy Kingfisher & 1 & 2 & Uncommon \\
Baglafetch Weaver & 2 & 2 & Uncommon \\
Banded Barbet & 8 & 3 & Frequent \\
Brown-throated Wattle-eye & 7 & 3 & Frequent \\
Beautiful Sunbird & 9 & 3 & Frequent \\
Black Cap & 7 & 3 & Frequent \\
Black Kite & 1 & 2 & Uncommon \\
Black-backed Puffback & 11 & 4 & Common \\
Black-headed Batis & 2 & 2 & Uncommon \\
Black-headed Weaver & 1 & 2 & Uncommon \\
Blue-breasted Bee-Eater & 2 & 2 & Uncommon \\
Blue-headed Coucal & 4 & 3 & Frequent
\end{tabular}




\begin{tabular}{|c|c|c|c|}
\hline Common Name & $\begin{array}{c}\text { Number of } \\
\text { individuals }\end{array}$ & Abundance score & Relative abundance \\
\hline Blue-throated Bee-eater & 13 & 4 & Common \\
\hline Blue-spotted Wood-Dove & 2 & 2 & Uncommon \\
\hline Cattle Egret & 2 & 2 & Uncommon \\
\hline Collard Sunbird & 2 & 2 & Uncommon \\
\hline Common Bulbul & 36 & 4 & Common \\
\hline Grey-backed Camaroptera & 18 & 4 & Common \\
\hline Sand Martin & 100 & 5 & Abundant \\
\hline Common Stonechat & 2 & 2 & Uncommon \\
\hline Double-toothed Barbet & 1 & 2 & Uncommon \\
\hline Eastern-grey Plantian-eater & 23 & 4 & Common \\
\hline Egyptian Goose & 2 & 2 & Uncommon \\
\hline European Turtle-Dove & 4 & 3 & Frequent \\
\hline Fan-tailed Widowbird & 5 & 3 & Frequent \\
\hline Great White Egret & 1 & 2 & Uncommon \\
\hline Greater Blue-eared Glossy- Starling & 5 & 3 & Frequent \\
\hline Grey Woodpecker & 7 & 3 & Frequent \\
\hline Grey-headed Sparrow & 10 & 3 & Frequent \\
\hline Hamerkop & 4 & 3 & Frequent \\
\hline Hemprich's Hornbill & 2 & 2 & Uncommon \\
\hline Black-headed Batis & 2 & 2 & Uncommon \\
\hline Laughing Dove & 13.1 & 4 & Common \\
\hline Lemon Dove & 19 & 4 & Common \\
\hline Little Bee-eater & 1 & 2 & Uncommon \\
\hline Malachite Kingfisher & 1 & 2 & Uncommon \\
\hline Narina's Trogon & 4 & 3 & Frequent \\
\hline Northern Black Flycatcher & 4 & 3 & Frequent \\
\hline Olivaceous Warbler & 6 & 3 & Frequent \\
\hline Olive Thrush & 8 & 3 & Frequent \\
\hline Marsh Warbler & 6 & 3 & Frequent \\
\hline Open-billed Stork & 1 & 2 & Uncommon \\
\hline Osprey & 1 & 2 & Uncommon \\
\hline Red-billed Firefinch & 10 & 3 & Frequent \\
\hline Red-cheeked Cordonbleu & 2 & 2 & Uncommon \\
\hline Red-eyed Dove & 17 & 4 & Common \\
\hline Red-winged Starling & 2 & 2 & Uncommon \\
\hline Ruppell's Robin-Chat & 15 & 4 & Common \\
\hline Scarlet-chested Sunbird & 7 & 3 & Frequent \\
\hline Silvery-cheeked Hornbill & 3 & 3 & Frequent \\
\hline Speckled Mousebird & 8 & 3 & Frequent \\
\hline Speckled Pigeon & 13 & 4 & Common \\
\hline Spectacled Weaver & 2 & 2 & Uncommon \\
\hline Striped Kingfisher & 2 & 2 & Uncommon \\
\hline Tropical Boubou & 13 & 4 & Common \\
\hline Variable Sunbird & 5 & 3 & Frequent \\
\hline Violet-Backed Starling & 13 & 4 & Common \\
\hline White-cheeked Turaco & 4 & 3 & Frequent \\
\hline White-headed Vulture & 1 & 2 & Uncommon \\
\hline Yellow Fronted Parrot & 13 & 4 & Common \\
\hline Yellow-fronted Thinkerbird & 6 & 3 & Frequent \\
\hline
\end{tabular}

